\section{Federation University ResearchOnline}

\section{https://researchonline.federation.edu.au}

Copyright Notice

This is the author's version of a work that was accepted for publication in Assessment Matters (12) 3457. Changes resulting from the publishing process, such as peer review, editing, corrections, structural formatting, and other quality control mechanisms may not be reflected in this document.

Copyright @ NZCER Press.

Copyright $(\odot$ NZCER Press. This is an article distributed under the terms of the Creative Commons Attribution License (https://creativecommons.org/licenses/by-nc-nd/4.0/), which permits copy and redistribute the material in any medium or format medium, provided the original work is properly credited. If you remix, transform, or build upon the material, you may not distribute the modified material. Commercial use is not permitted and modified material cannot be distributed. 


\title{
Classroom assessment as a reciprocal practice to develop students' agency: a social cognitive perspective
}

Anna Fletcher

Federation University, Churchill

\begin{abstract}
The links among theory, teaching practice and evidence of student learning have increasingly gained traction in the public discourse in much of the Western world, as educational policy makers seek to bring together accountability demands with the push for improvements in student learning. This paper draws on the notion of teaching and assessment as generations informed by diverse theoretical viewpoints. The paper pursues three goals. First, it identifies distinct elements of social-cognitive theory and the concept of triadic reciprocality in relation to the concepts of student agency and reciprocity between teachers and students in classroom assessment as a learning process. Second, the paper outlines the transformation of assessment practice over three generations of pedagogical theory. Third, it argues that social cognitive theory offers a recalibrated understanding of assessment as a student-centred learning process.
\end{abstract}

Keywords: assessment as learning, self-assessment, student agency, self-regulated learning, social cognitive theory, triadic reciprocality 


\section{Introduction}

The links among theory, teaching practice and evidence of student learning have increasingly gained traction in the public discourse in much of the Western world, as educational policy makers seek to bring together accountability demands with the push for improvements in student learning (Birenbaum et al., 2015; Black \& Wiliam, 2018; Hopmann, 2008). Despite earlier initiatives aimed at generating evidence-informed general principles which could be applied to analyse and explore the impact of teaching and learning (James \& Pollard, 2011), research into the links between learning theory foundations and assessment remain scant (Baird, Andrich, Hopfenbeck, \& Stobart, 2017; Black \& Wiliam, 2018).

This paper responds to the growing interest in clarifying the links between theory, teaching practice and learning evidence, by exploring these connections in the context of classroom assessment. Drawing on previous definitions (Black \& Wiliam, 2018; Davies \& Hill, 2009; Harlen, 1994; Shepard, 2000), the term 'classroom assessment' is used here to describe the process of gathering and interpreting evidence about student learning to inform teaching and enhance student learning. Within classroom assessment the teacher/teaching team make decisions about what is assessed, how the assessment is administered, and the procedures for interpreting results and making inferences about students' learning. Thus, classroom assessment is conceptualised in this paper as a term which may accommodate both formative and summative motives of assessment.

Assessment commonly is conceived as having three main purposes -for, as and oflearning (e. g. Australian Curriculum and Assessment Reporting Authority [ACARA], 2012; Griffin \& Care, 2014). As Hayward (2015) warns, prepositions that link assessment to learning are in danger of being turned into an unreflective mantra unless they are used to focus attention on different purposes for assessment. Similarly, Wiliam (2017, p. 400) asserts 
that assessment practices need to be examined in respect to the quality evidence of learning they generate, as "it is the focus on evidence that justifies the term 'assessment".

This article uses the following definitions to distinguish between the different purposes of classroom assessment. Assessment for learning (AfL) — also referred to as formative assessment — refers to classroom assessment that is embedded as part of the learning process, with the explicit aim of informing learners and teachers of the next steps needed to enhance a learner's understanding and skills (Black \& Wiliam, 2018; Cowie \& Bell, 1999; Klenowski, 2009). Assessment as Learning (AaL) is conceptualised as an embodiment of formative assessment with the purpose of positioning learners as critically reflective connectors between task requirements and the learning process (Dann, 2002; Earl, 2003; Fletcher, 2016, 2017), as co-owners of their learning process (Absolum, Flockton, Hattie, Hipkins, \& Reid, 2009). Assessment of Learning (AoL) is defined as a point in time procedure used for the purposes of enabling teachers and others to make inferences about students' progress and what has been learnt to date (Black \& Wiliam, 2018; Davies \& Hill, 2009).

This article begins by identifying distinct elements of social cognitive theory (Bandura, 1986) in relation to the concepts of student agency and reciprocity between teachers and students in classroom assessment as a learning process. It then explores assessment as transformational generations of pedagogical practice with a focus on the contrasting purposes and theory connections of classroom assessment. Drawing on Allal (2011), the term 'pedagogy' is understood to encompass theories to conceptualise teacherlearner transactions relating to how and why learning takes place; including the planning and enactment of teaching practice and curriculum considerations that frame the learning. Next, the paper presents social cognitive theory as a synthesis of cognitive constructivist and sociocultural theories. Using this blended approach, it explores assessment as a learning 
process which scaffolds students' agency and ability to self-regulate their learning. The term agency refers to the notion that people exert influence over their functioning and the course of events that result from their actions (Bandura, 2006). The concept of self-regulation denotes a learner's ability to control their thoughts, feelings and actions about a learning task by planning, monitoring and regulating the actions they take in pursuit of solving it (Zimmerman \& Schunk, 2011). Finally, an argument is presented that social cognitive theory may enable a broadened understanding of classroom assessment to emerge.

\section{Social cognitive theory and the concept of Triadic reciprocality}

This article focuses on learner agency as an integral part of AaL, for the purposes of advocating that social cognitive theory may offer formative assessment researchers a theoretical lens to conceptualise the agentic role of a student in the learning process, in a framework which integrates both individual and situational factors. As one reviewer of an earlier version of this article pointed out, within the formative assessment literature (unless from the French-speaking world) the adoption of social cognitive theory to conceptualise classroom assessment remains scarce. Social cognitive theory (Bandura, 1986) is founded on an agentic perspective, which holds that people intentionally exert influence over their functioning and the course of events that result from their actions (Bandura, 2006, 2012). As Biesta, Priestley, and Robinson (2015) point out, agency is something people $d o$, rather than a capacity, competence or property they have.

A central understanding within social cognitive theory is the notion that agency and human functioning generally, is the product of the reciprocal interplay among personal, situational and behavioural factors, which mutually influence one another. Bandura (1986) refers to this dynamic interplay of factors as triadic reciprocality. As illustrated in Figure 1, when conceptualised from a social cognitive perspective, learning and teaching are shaped by the reciprocal interplay among students' and teachers' intrapersonal influences (e.g. 
deductive reasoning, knowledge and skills, self-efficacy; self-beliefs and emotional reactions, degree of motivation, interest); the behaviour and learning actions students and teachers engage in when working on the task at hand (e.g. clarifying and sharing learning intentions and success criteria; providing and seeking feedback); and the situational /social environment forces of the classroom context (curriculum demands, scaffolding and support from the teacher and peers, resources and exemplars).

$<<<$ Please insert Figure 1 around here $>>>$

Social cognitive theory's adoption of an agentic perspective highlights how people have a hand in shaping events and the course their lives take. In particular, a person's confidence in their own ability to complete task - their self-efficacy — is viewed as a key constituent of the intrapersonal influences (Bandura, 2012). The agentic perspective also underpins how the situational context or social environment is perceived within triadic reciprocality. From a social cognitive stance, the environment is regarded as a flexible force, which may be imposed, selected, or constructed as a situational context. The imposed situation — such as the classroom context, or curriculum demands - is considered as affecting individual students and teachers whether they like it or not. However, there is some scope in how individual students and teachers interpret and react to it. Bandura (2012) suggests that in the main, the situational context is a backdrop which does not come into being unless selected and activated. Students and teachers activate and construct their situational context when they make choices about how and why learning takes place. For example, in a classroom assessment involving students using a planning template to guide their writing process (Fletcher, 2015); as a student determines the audience for the text they are about to write, the student's choice of an audience is both an interpretation and a reaction to the situational context of the task at hand. In Fletcher's (2015) study, a large proportion of students (68 of a total of 126 students) chose audiences of an age group similar to their own, 
which appeared to help them to relate to the audience. In turn, students' agency in choosing their audience may have contributed to the findings which indicated that students remained motivated and persisted with their learning as they drafted and edited their work. The issue of becoming motivated as a writer because of the audience, as well as the audience becoming motivated to engage with the written text, was repeatedly raised in student interviews in the study. Jeremy, a Year 6 student whose planning template indicated that his intended audience were students of a similar age, provided the following summary of what he perceived as the essence of being a good writer:

Well, if you're a good writer you can really engage the audience. You can really engage the people who are reading, and make them want to keep reading to find out what's happening. That's what I like.

Fletcher (2015) suggests that students' strategic planning and development of their work, was partially shaped by situational factors such as the planning template, combined with intrapersonal factors such as students' consideration of how their work may be received by their audience. In turn, students' level of motivation and effort to persist with their work reciprocated with these factors.

Similarly, when a teacher decides how to scaffold a learning activity which targets particular curriculum outcomes, his or her choices affect the course of learning and teaching. For example, Fletcher $(2015,2017)$ notes that teachers' choices in scaffolding feedback reciprocated with students' active role in the learning process which prompted them to seek help in addressing their learning learning goals. One of the teachers described how students' help seeking in turn prompted her to initiate conferences with small groups of students. She found that the conference format helped her provide feedback to the individual student, tailored around their proximal needs and where they were at in the learning process. 
In sum, the agentic foundation of the social cognitive theory when applied to a classroom context, holds that students and teachers create environments that enable them to exercise control of how and why learning takes place.

Agency

The notion of agency being shaped by the dynamic interplay among multiple factors is shared by others. For example, Emirbayer and Mische (1998) adopt the view that people's agency largely is shaped by the interplay of social and relational factors; behavioural components such as a person's habitual action which require their attention and effort; and internal factors such as how they go about problematising, deciding and implement actions effectively within particular circumstances. Similarly, Biesta et al. (2015) present a model of teacher agency which highlights how the 'doing' by teachers (their agency) is oriented to the future but informed by intrapersonal factors such as the teacher's past personal and professional experiences; and enacted in the present, situated context which is influenced by cultural, material and structural resources. The model derived from a two-year study into teacher agency against the backdrop of the implementation of Curriculum for Excellence in Scotland, which Biesta and his colleagues (2015) found to indicate that while agency partly relies on the beliefs that individual teachers bring to their practice, the development of agency also requires collective development and consideration.

The models presented by Emirbayer and Mische (1998) and Biesta et al. (2015) align with social cognitive theory by arguing there is a dynamic relationship of interplay among intrapersonal factors, the situational context and the actions people take. However, social cognitive theory adopts an explicit stance by arguing that there is a reciprocal relationship among the situational, interpersonal and behavioural factors that frame people's functioning. By contrast, Biesta et al. (2015) along with Emirbayer and Mische (1998), primarily view 
agency as a temporally embedded process of social and cultural engagement which is informed by the past.

Having outlined the concept of agency and the introduced readers to the social cognitive concept of triadic reciprocality (Bandura, 1986, 2012), this paper now turns to explore classroom assessment as transformational generations of pedagogical practice.

\section{Assessment in continuous transformation: Generations of assessment practice}

In her analysis of congruence between assessment practice and beliefs, James (2008) argues for developing valid assessment through explicit alignment among assessment, teaching and learning. Using the term 'generations' to signify how different assessment practices have come to maturity at different points in history, James (2008) asks whether blended approaches are possible. This paper seeks to further progress James' discussion of generations of assessment by positing that social cognitive theory may present an avenue of a blended, enriched approach to conceptualise classroom assessment. It is important to clarify that while the notion of generations suggests past eras — indeed three of the generations presented here can be traced back to the first few decades of the last century — these generations of assessment characteristics and practices prevail, which is why all are outlined in the present tense.

\section{The first generation: assessing the transmission of knowledge}

The first generation of assessment practices is characterised by a mechanistic approach to teaching and learning, which dates back to Edward Thorndike's 'effects of connection' (Thorndike, 1927). From this pedagogical stance of how and why learning takes place, learning is highly sequential and underpinned by the concept of learner readiness, with the assumption that the result is efficient learning (Koenig, 2010). This generation of classroom 
assessment is informed by behaviourist theories in which learning is a conditioned response to external stimuli. Therefore, this approach focuses on rote learning, as the theory holds that repetitions of the stimuli develop habitual responses, which through skill and drill become automatic.

Broadly speaking, within this first generation, complex skills are reduced into components which are taught and tested separately because it is assumed that complex understandings occur on the condition that more basic, prerequisite learnings have been mastered (Gipps, 1994). Importantly, assessment is regarded as separate to learning, providing evidence of the effectiveness with which knowledge has been transmitted by the teacher and absorbed by the learners (James, 2008), and indicating whether enough teacher reinforcement has occurred (Wiliam, 2017). Consequently, assessments take place under test conditions at the end of a unit of learning, in which the separate components of the taught tasks are reassembled into an overall task.

Direct Instruction (DI) and Explicit Instruction (EI) which involve a highly organised and controlled format of explicit teacher instruction (Howell, 2014; Killen, 2016) provide examples of first generation classroom assessment practice. In the DI approach, students' understanding of the content and the relevant skills are tested before the teacher moves on to the next stage (Howell, 2014). Killen (2016) explains that the instruction and learning process within DI tends to follow a sequence of five parts: (1) an overview in which students are told what they will learn and why. This may be communicated by the teacher reading from a script. (2) Teachers provide explicit explanations of the knowledge and skills, before giving the students the opportunity to demonstrate their initial understanding by responding to the teacher's questions. (3) When the teacher is confident that the students are ready, students are given guided practice of the lesson's knowledge and skill focus. The teacher closely supervises the students' guided practice. (4) Independent practice reinforces students' 
understanding. (5) The teacher analyses the evidence of what students have learnt before deciding whether students are ready to progress to the next stage of learning.

In respect of this paper's focus on student agency, DI presents a conflicting stance by positioning students as recipients of targeted, scripted instruction, whose guided practice is monitored. As the Good to Great school website puts it: "DI is built on the philosophy that 'if a student hasn't learned, the teacher hasn't taught'." (Good to Great Schools Australia, 2016, paragraph 8).

\section{From transmission of knowledge to sense making: the second generation}

The second generation of assessment practice suggests a shift in the learner's role, from a recipient of instruction to a constructor of understanding. The second generation also marks a shift from a linear model of learning to a model of networks and learning connections in different directions (Gipps, 1994). As the name indicates, cognitive learning theories focus on internal mental processes and their role in learning. The assumption is that learning is a process of knowledge construction by which learners interact with the environment, and link information from current experiences to previous knowledge (Gipps, 1994; Sullivan Palincsar \& Brown, 1989). This generation of pedagogy adopts a developmental perspective of learning by conceptualising that children learn by constructing increasingly complex cognitive structures (schema) to which new understandings are incorporated. Shepard (2000) highlights the importance that cognitive learning theorists attribute to the notion of students being able to transfer knowledge to new situations, because true understanding is seen as flexible, connected and generalizable. In relation to transfer, Resnick and Klopfer (1989), point out that while Piaget (1948/74) and his followers argued that knowledge acquired by memorisation is not real knowledge that can be used, Piaget's theories appeared to "deny the importance of specific knowledge and to set cultivation of thinking skills apart from learning subject matter.” (Resnick \& Klopfer, 1989, p. 3). Not surprisingly, such theoretical stances 
were an uneasy fit with the context of classroom practice and summative assessment regimes in schools. Resnick and Klopfer (1989) suggest that these difficulties prompted researchers within the field of cognitive educational theory to develop a new research direction based on constructivist learning theories about the nature of learning. The new direction in cognitive constructivism accommodated self-regulated learning theories (Resnick \& Klopfer, 1989; Sullivan Palincsar \& Brown, 1989), which put a clear focus on the student's role in the learning process in relation to contextual influences (Paris \& Newman, 1990). While the cognitive constructivist approach is closely aligned with the social cognitive theoretical framework presented in this paper, it lacks the latter's explicit focus on triadic reciprocality (Bandura, 1986). Also, social cognitive theory in this article is conceptualised as a blend of cognitive constructivist theory which provides a specific emphasis on the individual, together with socio-cultural theories which emphasises the social context.

In respect of classroom assessment, the focus within cognitive constructivism is on the individual learner's sense-making (Gipps, 1994; James, 2008). Classroom assessment within a of cognitive constructivist theoretical framework aims at gauging the depth of an individual's understanding. For instance, Shepard (2000) highlights self-assessment as serving both cognitive purposes and promoting self-regulated learning by increasing students' responsibility for their own learning by collaborating with teachers.

Assessment of learning in second-generation assessments tend to require the student to demonstrate cognitive skills by applying conceptual frameworks to find solutions to problems (James, 2008). Within this generation, classroom assessments of learning provide teachers an indication whether the misconceptions that a student may have brought to the classroom has been overcome (Wiliam, 2017). Second-generation classroom assessments are frequently time-limited, as speed of completion is assumed to correlate with the level of a student's acquisition of concepts (James, 2008). As students' understanding of a concept is 
being tested, assessments may include prompts in the form of particular materials, which the assessment task requires the student to interpret. A pertinent example of this type of assessment can be seen in Australia's National Assessment Program - Literacy And Numeracy (NAPLAN), which has all these features (ACARA, 2017).

\section{Transforming from individual sense making to social participation: the third generation}

The third generation of assessment practice presents a shift away from viewing learning as an acquisition of knowledge and understanding —instead learning is seen as a social practice of participation (James, 2008). For example, Gipps (1999) argues that while human agency drives the learning process, learning and understanding are not exclusively a product of the person acting but derives from an individual learner engaging in relational activities with others. Similarly, James (2008) describes learning as a social and collaborative activity, emphasising its collective importance by arguing: "Learning involves participation and what is learned is not the property of an individual but distributed within the social group" (p. 30)

As Gee (2008, p. 81) points out, sociocultural/situated theories accommodate "a variety of different perspectives developed in work using different disciplinary lenses", rather than constituting a singular school of thought. However, broadly speaking, learning is seen to involve both thought and action in a sociocultural, situated context (Gee, 2008; Gipps, 1999), as a member of a community of learners in a school (Klenowski \& Wyatt-Smith, 2014; Moss, 2008). The collective knowledge of the learning community is then internalised by the individual learner, who in turn contributes to the group with their knowledge (Edwards, 2005; Moss, Girard, \& Greeno, 2008). Learning and teaching are thus seen as a cyclic movement in which knowledge is created and distributed.

Assessment in this view is an interaction among the student, teacher and the assessment task within its social, historical and cultural context (Elwood, 2006; Klenowski \& Wyatt-Smith, 2014). Situated, cultural artefacts such as teachers' reflection journals and 
students' notebooks (Moss, 2008) and portfolios (Gipps, 1999) are seen as important classroom assessment tools which provide accounts of thought and language which provide evidence to support and guide further learning (James, 2008; Moss et al., 2008). Sociocultural assessment approaches tend to use qualitative methods to judge work, to form a holistic view, rather than quantified approaches to measurement (James, 2008). For example, Gipps (1999) argues that assessment of learning should be implemented as a procedure which elicits evidence of best performance, by allowing students to seek help from more able peers and adults, thus aligning with Vygotsky's (1978) notion of a zone of proximal development. As such, standardised assessments are regarded as problematic from a sociocultural stance, as they generally do not allow for best performance (Gipps, 1999). In addition, as noted by Klenowski (2015) writing in the context of Australia and particularly with Aboriginal students in mind, standardised assessments such as NAPLAN (mentioned above) generally do not accommodate for the cultural context, which raises validity problems.

\section{A synthesised stance to understand learning: Social cognitive theory}

As indicated in the introduction, this article aims to present social cognitive theory as a synthesis of cognitive constructivist and sociocultural theories. Using this blended approach, it explores assessment as a learning process which scaffolds students' agency and ability to self-regulate their learning. By positing that people are both producers and products of social systems (Bandura, 1997), social cognitive theory shares the sociocultural acknowledgement of social participation as a central aspect of learning. The two theories also share a focus on agency. As pointed out by Gipps (1999, p. 373), sociocultural theory recognises that agency is a significant factor in learning, but emphasises that learning is derived from being "engaged in relational activities with others". While the social cognitive view acknowledges the importance of relational activities and agency, it emphasises the reciprocal relationship 
between relational activities and how people have influence over what they do by exercising personal agency to motivate themselves, set goals and evaluate their progress (Bandura, 2001). Thus, from a social cognitive position, learning refers to the learner's agency and ability to self-regulate their learning within a social context (Cleary \& Zimmerman, 2004).

Poignantly, the French language literature on formative assessment presents a similar emphasis on individualised regulation of learning by stressing the importance of students' role in co-regulating learning (Allal, 2016; Perrenoud, 1998). Regulation in this context refers to four main processes (1) goal setting, (2) monitoring progress toward goal; (3) interpretation of feedback derived from monitoring; and (4) adjustment of goal-directed action and/or readjustment of the goal itself (Allal, 2010). It has been pointed out that both co-regulated and self-regulated learning tasks may be framed as individual or collaborative task contexts (Hadwin, Järvelä, \& Miller, 2011), so it is significant to note that Allal's definition of co-regulation puts the emphasis on students' strategic planning and control of action. By contrast, many self-regulated learning definitions adopt a broader scope by conceptualizing the term as relating to students' planning, monitoring and control of their thoughts, feelings and actions, (e. g. Hadwin et al., 2011; Pintrich, 2004; Wigfield, Klauda, \& Cambria, 2011; Zimmerman \& Schunk, 2011). The latter definition is adopted in this paper.

Nevertheless, French-speaking assessment researchers propose an enlarged conception of formative assessment which scaffolds students' active involvement in formative assessment through procedures such as self-assessment, reciprocal peer assessment and joint teacher-student assessment (Allal, 2016; Allal \& Lopez, 2005). This emphasis on student agency aligns with critique of what Reeve (2012) calls a unidirectional flow of instruction by which the teachers set tasks that students respond to. As Reeve puts it (2012, p. 161: "What is missing from such a conceptualization of student engagement [... is] students' 
constructive contribution into the flow of instruction they receive, as students try to enrich and personalize that instruction".

Expanding previous generational notions of the community as a distributor of knowledge which the individual internalises, the focal point of this paper is Assessment as Learning ( $\mathrm{AaL})$, which is conceptualised as a process shaped by the reciprocal connections among three domains. While the term AaL was coined almost twenty years ago (Dann, 2002; Earl, 2003), it remains a contested concept. For example, the term has been used to describe the instrumentalist focus on criteria compliance, in which assessment procedures and practices have come to completely dominate learning and learning experiences (Torrance, 2007). AaL has been viewed as a concept of 'procedural compliance' whereby 'learning' has been displaced in teachers' thinking about the purpose of formative assessment (Hume \& Coll, 2009). In addition, AaL has frequently been associated with students judging their own work, which raises validity and reliability concerns (Brown \& Harris, 2014).

Rather than viewing AaL as testing in place of instruction, or focusing on students' evaluation of their finished work, it is suggested in this paper that AaL is better understood as a process of dynamic interplay between the teacher and student, which explicitly scaffolds the student's agentic and metacognitive engagement in tailoring their learning to address the success criteria, as part of the learning process. Research findings suggest that students enjoy greater academic success as learners if they have developed the ability to activate and sustain thoughts, feelings and behaviours that are systematically oriented towards the attainment of personal goals (e. g. Bembenutty, 2011; Dignath \& Büttner, 2008; Putwain, Nicholson, \& Edwards, 2016). In other words: students who are able to self-regulate their learning tend to enjoy greater academic success. Agency and self-assessment are at the core of self-regulated learning. Self-assessment is defined as a variety of mechanisms and techniques through 
which students describe and evaluate the qualities of their own learning processes and products (Panadero, Brown, \& Strijbos, 2016; Panadero, Jonsson, \& Botella, 2017).

\section{Classroom assessment as a three-phase process}

Classroom assessment that supports students to develop self-regulated learning is frequently conceptualised as a three-phase process (Andrade \& Brookhart, 2016; Fletcher, 2016, 2017). Drawing on self-regulated learning theory (e. g. Pintrich, 2004; Zimmerman, 2000, 2011), the assessment process comprises a forethought, performance and a self-reflection phase (see Table 1).

Table 1

Students role in classroom assessment as a three-phase process (adapted from Zimmerman 2011)

\begin{tabular}{|c|c|c|}
\hline Forethought phase & Performance phase & Self-reflection phase \\
\hline $\begin{array}{l}\text { Teacher and student } \\
\text { transactions support students } \\
\text { to... } \\
\text { - } \text { analyse learning } \\
\text { intentions and success } \\
\text { criteria } \\
\text { - split overall learning } \\
\text { intentions and success } \\
\text { criteria into partial, task- } \\
\text { related goals } \\
\text { - explore possible learning } \\
\text { strategies to employ } \\
\text { - decide on what strategies } \\
\text { and partial goals they } \\
\text { will use to monitor } \\
\text { progress during } \\
\text { performance/drafting } \\
\text { phase } \\
\text { determine timelines for } \\
\text { partial goals }\end{array}$ & $\begin{array}{l}\text { Teacher and student } \\
\text { transactions support students } \\
\text { to... } \\
\text { - monitor their } \\
\text { understanding and seek } \\
\text { help } \\
\text { - check performance } \\
\text { against partial goals to } \\
\text { monitor progress } \\
\text { - } \text { seek feedback } \\
\text { - adjust use of strategies }\end{array}$ & $\begin{array}{l}\text { Teacher and student } \\
\text { transactions support } \\
\text { students to... } \\
\text { - identify strengths and } \\
\text { areas to improve for } \\
\text { next time } \\
\text { - attribute reasons for } \\
\text { success and challenges }\end{array}$ \\
\hline
\end{tabular}


In the forethought phase, the teachers carefully support the students through the process of setting up the task, for example a writing project (e. g. Fletcher, 2016, 2017). Within the forethought phase, students analyse the task, set partial goals for segments of the task and identify appropriate learning strategies (Andrade \& Valtcheva, 2009; Fletcher, 2016; Panadero \& Alonso-Tapia, 2013). Students' planning in this phase are an important aspect of self-assessment (Andrade, 2010; Panadero \& Alonso-Tapia, 2013). By understanding explicit criteria, students are able to set more realistic goals for themselves, which in turn is thought to contribute to their level of motivation as they persist with tasks (Fletcher, 2016; Jonsson, 2014; Panadero \& Alonso-Tapia, 2013; Panadero, Jonsson, \& Strijbos, 2016). Also, having a clear understanding the learning goals, enable students and teachers to take action to close the learning gaps (Andrade \& Brookhart, 2016; Fletcher, 2017; Hattie \& Timperley, 2007; Wiliam, 2011).

From a social cognitive perspective, the complexity of the forethought phase is highlighted by the notion of triadic reciprocality between intrapersonal factors such the student's cognition, self-efficacy, and interest; the situational context in the form of teacher support, task requirements and task purpose; and subsequent learning actions the teacher and student engage in during goal setting and strategic planning (Zimmerman, 2011). Importantly, the forethought phase does not entail a uni-directional flow of teacher instruction and student response (Reeve, 2012). For example, Fletcher $(2015,2017)$ in a onesetting study involving ten teachers and 256 primary students in Australia, notes that the forethought phase AaL appears to have prompted changes in the teachers' practice. The cross-sectional study used a detailed planning template to scaffold teaching and learning in the forethought step. In accordance with the notion of triadic reciprocality, the teachers in Fletcher's (2017) study appeared to have to change their practice by placing greater emphasis 
and more explicit instructions during the forethought stage of the learning process, than they normally would. The study also found that students exercised agency in seeking feedback from their teachers. Similarly, others emphasise that feedback processes need to shift from a unilateral act initiated by teachers to a co-constructed sequence of dialogues between students and teachers (Boud \& Molloy, 2013; Yang \& Carless, 2013), thus echoing the notion of triadic reciprocality.

The performance phase involves students exercising self-control by employing learning strategies to solve the task at hand. Within this phase, students monitor and regulate their learning progress, with support from their teacher - for example in the form of conferencing. Cleary and Labuhn (2013), writing in the context of science-based selfregulation interventions with high-school students in the form of case studies, point out that conversations between students and teachers about strategies which students can enact to support their own learning fulfil an important motivational purpose by helping students sustain their efforts as they learn. Furthermore, these conversations need to occur both during the forethought phase, as students develop their plans and during the performance phase, as students use the tactics (Cleary \& Labuhn, 2013). Andrade and Brookhart (2016) assert that monitoring learners progress toward a goal, along with feedback are central purposes of both classroom assessment and self-regulation. Often, this entails students to engage in selfassessment as they describe, reflect on and assign merit to the quality of their work, judge the degree to which it meets the success criteria and revise their work accordingly (Andrade, 2010; Panadero et al., 2017).

Self-assessment as a strategy for students to monitor their learning progress is supported by empirical studies such as the randomized controlled study involving thirty-one Year 6 classes at seventeen school is the Netherlands (Meusen-Beekman, Joosten-ten Brinke, \& Boshuizen, 2016). In this study, students were allowed to work at their own pace as they 
completed three writing assignments. During the forethought phase teachers and students established, discussed and set the criteria for the writing assignments. In the performance phase, students used checklists to indicate where they were going in the learning process, and how and when to reach their learning goals. As the students worked on their drafts, their progress was carefully monitored either by a peer or by themselves. Teachers also provided feedback and used questions to encourage students to reflect on their progress, adjust faulty strategies and monitor their work. The study findings indicated that both peer-and selfgenerated feedback as part of classroom assessment had a statistically significant, positive association with self-regulation and intrinsic motivation (Meusen-Beekman et al., 2016).

The third phase of classroom assessment is the self-reflection phase. It is necessary to qualify this term, because in this paper it refers to the final phase of the classroom assessment process. However, this phase is generally conceived of as a step in a cycle, in which the selfreflection phase prompts a new iteration of the cycle, starting with forethought (Andrade \& Brookhart, 2016; Chen \& Rossi, 2013; Cleary \& Labuhn, 2013; Zimmerman, 2000, 2011). The self-reflection phase entails students and teachers evaluating the effectiveness of the strategies they have employed. In addition, both identify the strengths and weaknesses of their approach in relation to the task criteria and set goals. In line with formative assessment principles, the self-reflection phase needs to inform future learning and teaching, if it is to have a positive impact on learning. As Panadero and Alonso-Tapia (2013) point out in their theoretical and practical connotations of self-assessment, students need to understand that it is possible to learn from mistakes and success.

From a perspective of social cognitive theory, the self-reflection phase again illustrates the reciprocal relationship between intrapersonal, behavioural and situational influences. Student's cognitive and metacognitive reflection of their own learning and the effectiveness of the various learning actions (e. g. asking questions to clarify success criteria, 
seeking feedback, checking progress against goals etc.) is framed by situational factors such as the task context, curriculum demands and success criteria (Fletcher, 2015). The same applies to teachers as they reflect on how they scaffolded instruction and helped their students develop the knowledge and skills, and the evidence of students' learning.

\section{Conclusion}

This paper seeks to offer a recalibrated perspective of assessment as a reciprocal practice by examining classroom assessment through social cognitive theory. The paper's exploration of assessment as generations of pedagogical practice (James, 2008) highlights how diverse theoretical lenses provide different conceptual and practical insights. The paper presents a conceptual and practical framework of formative classroom assessment to scaffold students' development of agency and self-regulated learning skills as a highly individualised form of goal-directed learning. Student-teacher transactions are viewed as shaped by a reciprocal relationship among intrapersonal, situational and behavioural influences, which entails students making strategic choices as they plan and monitor their learning, thereby developing competence to self-regulate their learning. 
References

Absolum, M., Flockton, L., Hattie, J., Hipkins, R., \& Reid, I. (2009). Directions for assessment in New Zealand: Developing students' assessment capabilities. Wellington: Ministry of Education Retrieved from Accessed from Te Kete Ipurangi Assessment Online: http://assessment.tki.org.nz/Research-and-readings.

Australian Curriculum, Assessment and Reporting Authority [ACARA]. (2012). The Shape of the Australian Curriculum, Version 3. Sydney: ACARA Retrieved from http://www.acara.edu.au/verve/_resources/The_Shape_of_the_Australian_Curriculum V3.pdf.

ACARĀ. (2017). National Assessment Program - Literacy and Numeracy Achievement in Reading, Writing, Language Conventions and Numeracy: National Report for 2017. Sydney: Australian Curriculum, Assessment and Reporting Authority (ACARA).

Allal, L. (2010). Assessment and the regulation of learning. In P. Peterson, E. Baker, \& B. McGraw (Eds.), International encyclopedia of education (Vol. 3, pp. 348-352). Oxford: Elsevier.

Allal, L. (2011). Pedagogy, didactics and the co-regulation of learning: a perspective from the French-language world of educational research. Research Papers in Education, 26(3), 329-336. doi:10.1080/02671522.2011.595542

Allal, L. (2016). The Co-Regulation of Student Learning in an Assessment for Learning Culture. In D. Laveault \& L. Allal (Eds.), Assessment for Learning: Meeting the Challenge of Implementation (pp. 259-273). London: Springer.

Allal, L., \& Lopez, L. M. (2005). Formative assessment of learning: A review of publications in French: OECD.

Andrade, H. (2010). Student as the definite source of formative assessment: Academic selfassessment and the self-regulation of learning. In J. J. Andrade \& G. J. Cizek (Eds.), Handbook of Formative Assessment (pp. 90-105). New York: Routledge.

Andrade, H., \& Valtcheva, A. (2009). Promoting Learning and Achievement Through SelfAssessment. Theory Into Practice, 48(1), 12-19. doi:10.1080/00405840802577544

Andrade, H. L., \& Brookhart, S. M. (2016). The Role of Classroom Assessment in Supporting Self-Regulated Learning. In D. Laveault \& L. Allal (Eds.), Assessment for Learning: Meeting the Challenge of Implementation (pp. 293-309). London: Springer.

Baird, J.-A., Andrich, D., Hopfenbeck, T. N., \& Stobart, G. (2017). Assessment and learning: fields apart? Assessment in Education: Principles, Policy \& Practice, 24(3), 317-350. doi:10.1080/0969594X.2017.1319337

Bandura, A. (1986). Social foundations of thought and action : A social cognitive theory Englewood Cliffs, N.J.: Prentice-Hall.

Bandura, A. (1997). Self-Efficacy: The Exercise of Control. New York: W. H. Freeman and Company.

Bandura, A. (2001). Social Cognitive Theory: An Agentic Perspective. Annual Review of Psychology, 52(1), 1-26.

Bandura, A. (2006). Toward a Psychology of Human Agency. Perspectives on Psychological Science, 1(2), 164-180. doi:10.2307/40212163

Bandura, A. (2012). On the Functional Properties of Perceived Self-Efficacy Revisited. Journal of Management, 38(1), 9-44. doi:10.1177/0149206311410606

Bembenutty, H. (2011). Academic Delay of Gratification and Academic Achievement. In H. Bembenutty (Ed.), Self-Regulated Learning (pp. 55-65). San Fransisco: Jossey-Bass.

Biesta, G., Priestley, M., \& Robinson, S. (2015). The role of beliefs in teacher agency. Teachers and Teaching, 21(6), 624-640. doi:10.1080/13540602.2015.1044325 
Birenbaum, M., DeLuca, C., Earl, L., Heritage, M., Klenowski, V., Looney, A., . . WyattSmith, C. (2015). International trends in the implementation of assessment for learning: Implications for policy and practice. Policy Futures in Education, 13(1), 117-140. doi:10.1177/1478210314566733

Black, P., \& Wiliam, D. (2018). Classroom assessment and pedagogy. Assessment in Education: Principles, Policy \& Practice, 1-25. doi:10.1080/0969594X.2018.1441807

Boud, D., \& Molloy, E. (2013). Rethinking models of feedback for learning: the challenge of design. Assessment \& Evaluation in Higher Education, 38(6), 698-712. doi:10.1080/02602938.2012.691462

Brown, G. T. L., \& Harris, L. R. (2014). The future of self-assessment in classroom practice: Reframing self- assessment as a core competency. Frontline Learning Research, 2(1), 22-30. doi:http://dx.doi.org/10.14786/flr.v2i1.24

Chen, P. P., \& Rossi, P. D. (2013). Utilizing claibration accuracy information with adolescents to improve academic learning and performance. In H. Bembenutty, T. J. Cleary, \& A. Kitsantas (Eds.), Applications of Self-Regulated Learning across Diverse Disciplines: A Tribute to Barry J. Zimmerman (pp. 263-297). Charlotte, USA: Information Age Publishing Inc.

Cleary, T. J., \& Labuhn, S. (2013). Application of Cyclical Self-Regulation Interventions in Science-Based Contexts. In H. Bembenutty, T. J. Cleary, \& A. Kitsantas (Eds.), Applications of Self-Regulated Learning across Diverse Disciplines: A Tribute to Barry J. Zimmerman (pp. 89-124). Charlotte, USA: Information Age Publishing Inc.

Cleary, T. J., \& Zimmerman, B. J. (2004). Self-regulation empowerment program: A schoolbased program to enhance self-regulated and self-motivated cycles of student learning. Psychology in the Schools, 41(5), 537-550. doi:10.1002/pits. 10177

Cowie, B., \& Bell, B. (1999). A Model of Formative Assessment in Science Education. Assessment in Education: Principles, Policy \& Practice, 6(1), 101-116. doi:10.1080/09695949993026

Dann, R. (2002). Promoting Assessment as Learning. London: RoutledgeFalmer.

Davies, A., \& Hill, M. (2009). Making Classroom Assessment Work: New Zealand edition. Wellington: NZCER Press.

Dignath, C., \& Büttner, G. (2008). Components of fostering self-regulated learning among students. A meta-analysis on intervention studies at primary and secondary school level. Metacognition Learning, 3(3), 231-264. doi:10.1007/s11409-008-9029-x

Earl, L. M. (2003). Assessment as learning: Using classroom assessment to maximize student learning. Thousand Oaks; London; New Delhi: Corwin Press.

Edwards, A. (2005). Let's get beyond community and practice: the many meanings of learning by participating. The Curriculum Journal, 16(1), 49-65. doi:10.1080/0958517042000336809

Elwood, J. (2006). Formative assessment: possibilities, boundaries and limitations. Assessment in Education: Principles, Policy \& Practice, 13(2), 215-232. doi:10.1080/09695940600708653

Emirbayer, M., \& Mische, A. (1998). What is Agency? American Journal of Sociology, 103(4), 962.

Fletcher, A. (2015). Student-Directed Assessment as a learning process for primary students: A mixed-methods study. (Doctor of Philosophy Thesis), Charles Darwin University, Australia. Retrieved from https://espace.cdu.edu.au/view/cdu:50323

Fletcher, A. K. (2016). Exceeding expectations: scaffolding agentic engagement through assessment as learning. Educational Research, 58(4), 400-419. doi:10.1080/00131881.2016.1235909 
Fletcher, A. K. (2017). Help seeking: agentic learners initiating feedback. Educational Review, 1-20. doi:10.1080/00131911.2017.1340871

Gee, J. P. (2008). A sociocultural perspective on opportunity to learn. In P. A. Moss, D. C. Pullin, J. P. Gee, E. H. Haertek, \& L. J. Young (Eds.), Assessment, equity, and opportunity to learn (pp. 76-108). New York: Cambridge University Press.

Gipps, C. (1994). Beyond Testing: Towards a theory of educational assessment. Milton Park: Falmer Press.

Gipps, C. (1999). Socio-Cultural Aspects of Assessment. Review of research in education, 24(1), 355-392. doi:10.2307/1167274

Good to Great Schools Australia. (2016). Good to Great Schools. Retrieved from http://www.goodtogreatschools.org.au/ABOUT/about-ggsa

Griffin, P., \& Care, E. (2014). Introduction. In P. Griffin (Ed.), Assessment for Teaching (pp. 1-12). Port Melbourne: Cambridge.

Hadwin, A. F., Järvelä, S., \& Miller, M. (2011). Self-Regulated, Co-Regulated, and Socially Shared Regulation of Learning. In B. J. Zimmerman \& D. H. Schunk (Eds.), Handbook of Self-Regulation of Learning and Performance (pp. 65-84). New York; London: Routledge.

Harlen, W. (1994). Enhancing Quality in Assessment: A publication of the BERA Policy Task Group on Assessment BERA Policy task group on assessment. London: Paul Chapman.

Hattie, J., \& Timperley, H. (2007). The Power of Feedback. Review of Educational Research, 77(1), 81-112. doi:10.3102/003465430298487

Hayward, L. (2015). Assessment is learning: the preposition vanishes. Assessment in Education: Principles, Policy \&amp; Practice, 22(1), 27-43. doi:10.1080/0969594X.2014.984656

Hopmann, S. T. (2008). No child, no school, no state left behind: schooling in the age of accountability. Journal of Curriculum Studies, 40(4), 417-456. doi:10.1080/00220270801989818

Howell, J. (2014). Teaching and learning: building effective pedagogies. South Melbourne: Oxford University Press.

Hume, A., \& Coll, R. K. (2009). Assessment of learning, for learning, and as learning: New Zealand case studies. Assessment in Education: Principles, Policy \& Practice, 16(3), 269-290. doi:10.1080/09695940903319661

James, M. (2008). Assessment and Learning. In S. Swaffield (Ed.), Unlocking Assessment: Understanding for reflection and application (pp. 20-35). Abingdon: Routledge.

James, M., \& Pollard, A. (2011). TLRP's ten principles for effective pedagogy: rationale, development, evidence, argument and impact. Research Papers in Education, 26(3), 275-328. doi:10.1080/02671522.2011.590007

Jonsson, A. (2014). Rubrics as a way of providing transparency in assessment. Assessment \& Evaluation in Higher Education, 39(7), 840-852. doi:10.1080/02602938.2013.875117

Killen, R. (2016). Effective teaching strategies: Lessons from research and practice (Seventh ed.). Melbourne: Cengage.

Klenowski, V. (2009). Assessment for Learning revisited: an Asia-Pacific perspective. Assessment in Education: Principles, Policy \& Practice, 16(3), 263-268. doi:10.1080/09695940903319646

Klenowski, V. (2015). Questioning the validity of the multiple uses of NAPLAN data. In B. Lingard, G. Thompson, \& S. Sellar (Eds.), National Testing in Schools: An Australian assessment (pp. 44-56). London: Routledge.

Klenowski, V., \& Wyatt-Smith, C. (2014). Assessment for Education: Standards, Judgement and Moderation. London, Los Angeles, New Delhi, Singapore: Sage. 
Koenig, R. (2010). Learning for Keeps: Teaching the Strategies Essential for Creating Independent Learnings. Alexandria, VA, USA: ASCD.

Meusen-Beekman, K. D., Joosten-ten Brinke, D., \& Boshuizen, H. P. A. (2016). Effects of formative assessments to develop self-regulation among sixth grade students: Results from a randomized controlled intervention. Studies in Educational Evaluation, 51, 126-136. doi:https://doi.org/10.1016/j.stueduc.2016.10.008

Moss, P. (2008). Sociocultural Implications for Assessment 1: Classroom assessment. In P. A. Moss, D. C. Pullin, J. P. Gee, E. H. Haertek, \& L. J. Young (Eds.), Assessment, equity, and opportunity to learn (pp. 222-258). New York: Cambridge University Press.

Moss, P., Girard, B., \& Greeno, J. (2008). Sociocultural Implications for Assessment II: Professional Learning, Evaluation and Accountability. In P. A. Moss, D. C. Pullin, J. P. Gee, E. H. Haertek, \& L. J. Young (Eds.), Assessment, equity, and opportunity to learn (pp. 295-332). New York: Cambridge University Press.

Panadero, E., \& Alonso-Tapia, J. (2013). Self-assessment: Theoretical and Practical Connotations. When it Happens, How is it Acquired and what to do to Develop it in our Students. Autoevaluación: Connotaciones teóricas y prácticas. Cuándo ocurre, cómo se adquiere y qué hacer para potenciarla en nuestro alumnado. Electronic Journal of Research in Educational Psychology, 11(2), 551-576. doi:10.14204/ejrep.30.12200

Panadero, E., Brown, G. T. L., \& Strijbos, J.-W. (2016). The Future of Student SelfAssessment: a Review of Known Unknowns and Potential Directions. Educational Psychology Review, 28(4), 803-830. doi:10.1007/s10648-015-9350-2

Panadero, E., Jonsson, A., \& Botella, J. (2017). Effects of self-assessment on self-regulated learning and self-efficacy: Four meta-analyses. Educational Research Review, 22, 7498. doi:10.1016/j.edurev.2017.08.004

Panadero, E., Jonsson, A., \& Strijbos, J.-W. (2016). Scaffolding Self-Regulated Learning Through Self-Assessment and Peer Assessment: Guidelines for Classroom Implementation. In D. Laveault \& L. Allal (Eds.), Assessment for Learning: Meeting the Challenge of Implementation (pp. 311-326). New York: Springer.

Paris, S. G., \& Newman, R. S. (1990). Development Aspects of Self-Regulated Learning. Educational Psychologist, 25(1), 87.

Perrenoud, P. (1998). From Formative Evaluation to a Controlled Regulation of Learning Processes. Towards a wider conceptual field. Assessment in Education: Principles, Policy \& Practice, 5(1), 85-102. doi:10.1080/0969595980050105

Pintrich, P. R. (2004). A Conceptual Framework for Assessing Motivation and SelfRegulated Learning in College Students. Educational Psychology Review, 16(4).

Putwain, D. W., Nicholson, L. J., \& Edwards, J. L. (2016). Hard to reach and hard to teach: supporting the self-regulation of learning in an alternative provision secondary school. Educational Studies, 42(1), 1-18. doi:10.1080/03055698.2015.1108839

Reeve, J. (2012). A Self-determination Theory Perspective on Student Engagement. In S. L. Christenson, A. L. Reschly, \& C. Wylie (Eds.), Handbook of Research on Student Engagement (pp. 149-172). New York: Springer.

Resnick, L. B., \& Klopfer, L. E. (1989). Toward the Thinking Curriculum: an overview. In L. B. Resnick \& L. E. Klopfer (Eds.), Toward the Thinking Curriculum: Current Cognitive Research. 1989 ASCD Yearbook (pp. 1-18). Alexandria, VA, USA: ASCD.

Shepard, L. A. (2000). The Role of Assessment in a Learning Culture. Educational Researcher, 29(7), 4-14. doi:10.3102/0013189X029007004

Sullivan Palincsar, A., \& Brown, A. L. (1989). Instruction for Self-Regulated Reading. In L. B. Resnick \& L. E. Klopfer (Eds.), Toward the Thinking Curriculum: Current 
Cognitive Research. 1989 ASCD Yearbook (pp. 19-39). Alexandria, VA, USA: ASCD.

Thorndike, E. L. (1927). The Law of Effect. The American Journal of Psychology, 39(1/4), 212-222. doi:10.2307/1415413

Torrance, H. (2007). Assessment as learning? How the use of explicit learning objectives, assessment criteria and feedback in post-secondary education and training can come to dominate learning. . Assessment in Education: Principles, Policy \& Practice, 14(3), 281-294. doi:10.1080/09695940701591867

Vygotsky, L. S. (1978). Mind in Society: The Development of Higher Psychological Processes. Cambridge, Massachusetts; London: Harvard University Press.

Wigfield, A., Klauda, S. L., \& Cambria, J. (2011). Influences on the Development of Academic Self-Regulatory Processes. In B. J. Zimmerman \& D. H. Schunk (Eds.), Handbook of Self-Regulation of Learning and Performance (pp. 33-48). New York; London: Routledge.

Wiliam, D. (2011). Embedded formative assessment. Bloomington, USA: Solution Tree Press.

Wiliam, D. (2017). Assessment and learning: some reflections. Assessment in Education: Principles, Policy \& Practice, 24(3), 394-403. doi:10.1080/0969594X.2017.1318108

Yang, M., \& Carless, D. (2013). The feedback triangle and the enhancement of dialogic feedback processes. Teaching in Higher Education, 18(3), 285-297. doi:10.1080/13562517.2012.719154

Zimmerman, B. J. (2000). Attaining Self-Regulation: A Social Cognitive Perspective. In M. Boerkaerts, P. R. Pintrich, \& M. Zeidner (Eds.), Handbook of Self-Regulation (pp. 1339). Burlington, USA; San Diego, USA; London: Elsevier Academic Press.

Zimmerman, B. J. (2011). Motivational sources and outcomes of self-regulated learning and performance. In B. J. Zimmerman \& D. H. Schunk (Eds.), Handbook of selfregulation of learning and performance (pp. 49-64). New York; London: Routledge.

Zimmerman, B. J., \& Schunk, D. H. (2011). Self-Regulated Learning and Performance: An Introduction and an Overview. In B. J. Zimmerman \& D. H. Schunk (Eds.), Handbook of Self-Regulation of Learning and Performance (pp. 1-12). New York; London: Routledge. 